\title{
Sosialisasi dan Pelatihan Penggunaan Aplikasi Untuk Membantu Pengelompokkan Menu di Wisanggeni Coffee
}

\author{
Socialization and Training Using Applications for Grouping Menu at Wisanggeni \\ Coffee
}

\author{
Hartatik $^{1}$, Andri Syafrianto ${ }^{2}$ \\ ${ }^{1}$ Program Studi Manajemen Informatika, Fakultas Ilmu Komputer, Universitas AMIKOM Yogyakarta, \\ Indonesia \\ ${ }^{2}$ Program Studi Informatika, STMIK El Rahma Yogyakarta, Indonesia \\ e-mail: ${ }^{1}$ hartatik@amikom.ac.id, ${ }^{2}$ andrisyafrianto@gmail.com
}

\begin{abstract}
Abstrak
Wisanggeni Coffee adalah sebuah cafe yang terletak di kaki bukit Gunung Merapi. Ketatnya persaingan bisnis menuntut pemilik Wisanggeni Coffee untuk terus berinovasi dalam setiap penentuan strategi bisnisnya. Beberapa permasalahan yang ditemukan di adalah persaingan bisnis yang ketat membuat trend penjualan stagnan. Selain itu pemilik kesulitan untuk mendapatkan pola pembelian konsumen. Pola pembelian yang tidak terprediksi membuat pemilik kesulitan dalam penentuan stok bahan makanan, minuman dan souvenir yang dijual. Kurang terprediksinya pola konsumen juga sering membuat kehilangan kesempatan untuk menjual makanan, minuman dan souvenir karena out of stock. Memanfaatkan ilmu yang ada di bidang komputer yaitu asosiasi untuk mendapatkan pola pembelian konsumen di "Wisanggeni Coffee". Aplikasi yang dibangun akan menggunakan metode apriori. Metode apriori akan menganalisa pola pembelian konsumen 1 bulan terakhir guna mendapatkan pola asosiasi antar produk makanan, minuman dan souvenir yang dijual. Hasil dari pengabdian ini adalah keinginan pemilik dalam membangun sistem asosiasi cukup baik. Pemilik langsung menerapkan aplikasi baik dalam pola menawarkan menu maupun mengatur tata letak souvenir di rak penjualan. Sebelumnya kami menargetkan sampai pada evaluasi hasil penerapan aplikasi apakah bisa meningkatkan penjualan. Namun karena pandemi Covid-19 tidak kunjung selesai, evaluasi ini kami tunda hingga kegiatan wisata pulih kembali.
\end{abstract}

Kata kunci-Asosiasi, Apriori, Menu, Souvenir

\begin{abstract}
Wisanggeni Coffee is a cafe located at the foot of Mount Merapi hill. The intense business competition demands Wisanggeni Coffee owners to continue to innovate in every determination of their business strategy. Some of the problems found in the business are tight business competition which makes the sales trend stagnant. In addition, the owner finds it difficult to get consumer buying patterns. Unpredictable buying patterns make it difficult for the owner to determine the stock of food, beverages and souvenirs being sold. The unpredictable pattern of consumers also often makes them lose opportunities to sell food, beverages and souvenirs because they are out of stock. Utilizing existing knowledge in the field of computers, namely associations to get consumer buying patterns at Wisanggeni Coffee. Applications built will use the a priori method. The priori method will analyze the purchasing patterns of consumers in the last 1 month in order to obtain the association pattern between the food, beverage and souvenir products sold. The result of this dedication is that the owner's desire to build a system of association is quite good. The owner immediately implemented the application both in the pattern of offering menus and arranging the layout of souvenirs on the sales shelf. Previously we targeted to evaluate the results of implementing the application whether it could increase sales. However, because the Covid-19 pandemic has not yet been completed, we have postponed this evaluation until tourism activities recover.
\end{abstract}

Keyword-Association, Apriori, Menu, Souvenir

\section{PENDAHULUAN}

"Wisanggeni Coffee" adalah sebuah cafe yang terletak di kaki bukit Gunung Merapi tepatnya di Palemsari, Umbulharjo, Kec. Cangkringan, Kabupaten Sleman, Daerah Istimewa 
Yogyakarta 55583. Cafe dengan tampilan yang cukup unik bertema retro, pemandangan yang begitu indah, suasana cafe yang sejuk, lengkapnya menu makanan dan minuman yang ditawarkan, serta banyaknya oleh-oleh yang bisa dibeli wisatawan membuat "Wisanggeni Coffee" sering menjadi tempat transit para wisatawan setelah mengikuti kegiatan wisata "Lava Tour Merapi". Beberapa spot wisata "Wisanggeni Coffee" bisa dilihat pada Gambar 1.

"Wisanggeni Coffee" dimiliki oleh seorang seniman bernama Bapak Hary Jaran. Ketatnya persaingan bisnis menuntut pemilik "Wisanggeni Coffee" untuk terus berinovasi dalam setiap penentuan strategi bisnisnya. Cara yang sudah dilakukan oleh pemilik "Wisanggeni Coffee" untuk menaikkan omset penjualan diantaranya dengan merenovasi tampilan cafe dengan tema retro agar berbeda dengan cafe lainnya. Cara lainnya dengan menyediakan menu makanan, minuman dan oleh-oleh yang lengkap bagi wisatawan. Namun cara ini belum bisa memberi omset sesuai yang diharapkan oleh pemilik. Semakin menjamurnya UMKM sejenis yang menawarkan tempat transit bagi wisatawan "Lava Tour" di kaki bukit Merapi seperti Merapi Coffee, Warung Jahe Merapi "ATMO", Kopi Lereng Merapi membuat trend penjualan "Wisanggeni Coffee" semakin hari stagnan bahkan ada kalanya menurun.

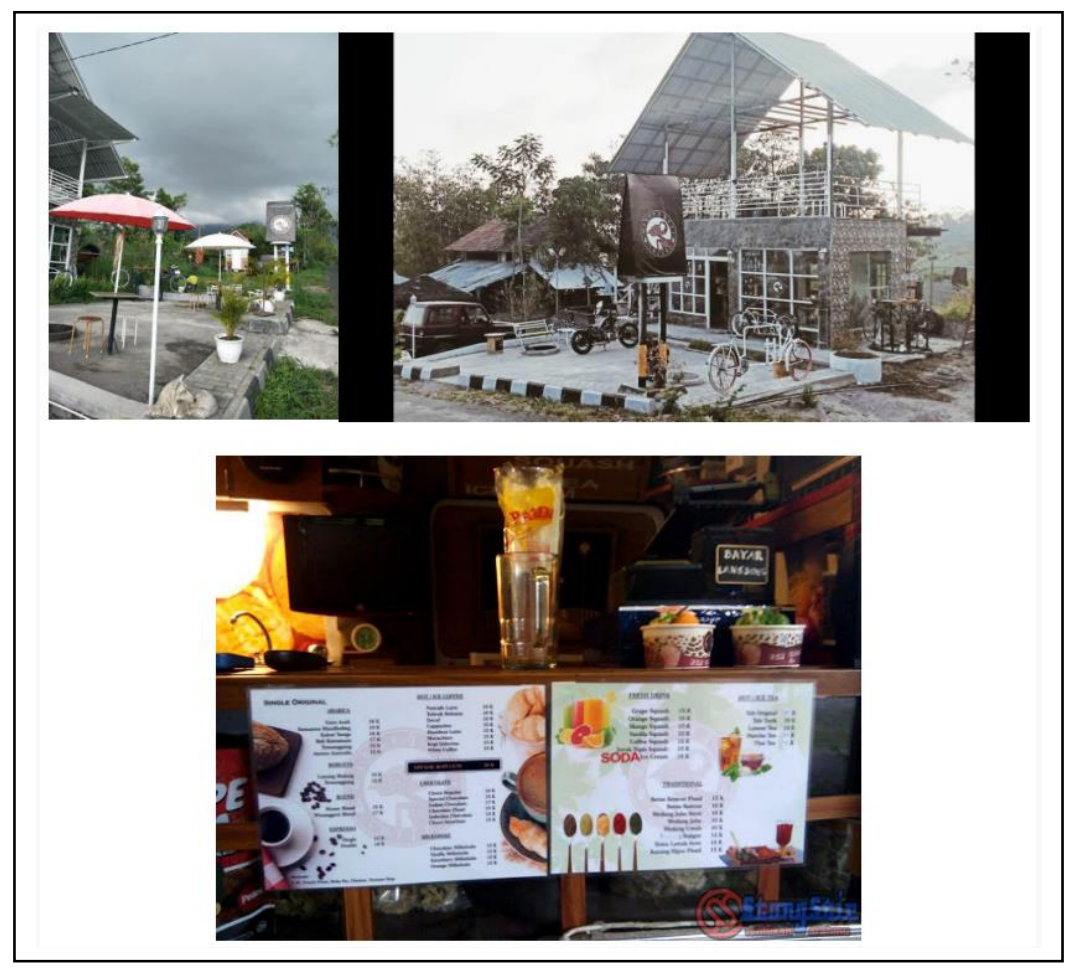

Gambar 1. Spot Wisanggeni Coffee

Dari hasil survei dan wawancara dengan pemilik "Wisanggeni Coffee" dapat disimpulkan ada beberapa poin yang menjadi permasalahan mitra :

1. Persaingan bisnis yang ketat membuat trend penjualan "Wisanggeni Coffee" semakin hari stagnan bahkan terkadang menurun.

2. Pemilik kesulitan untuk mendapatkan pola pembelian konsumen.

3. Pola pembelian yang tidak terprediksi membuat pemilik "Wisanggeni Coffee" kesulitan dalam penentuan stok bahan makanan, minuman dan souvenir yang dijual. Akibatnya stok bahan makanan dan minuman yang tidak bisa tahan lama seringkali terbuang karena tidak laku terjual.

4. Kurang terprediksinya pola konsumen juga membuat "Wisanggeni Coffee" seringkali kehilangan kesempatan untuk menjual makanan, minuman dan souvenir karena out of stock. 
Solusi permasalahan mitra yang diusulkan adalah :

1. Memanfaatkan ilmu yang ada di bidang komputer yaitu asosiasi untuk mendapatkan pola pembelian konsumen di "Wisanggeni Coffee". Aplikasi yang dibangun akan menggunakan metode apriori. Metode apriori akan menganalisa pola pembelian konsumen 1 bulan terakhir guna mendapatkan pola asosiasi antar produk makanan, minuman dan souvenir yang dijual di "Wisanggeni Coffee". Pola asosiasi antar produk akan digunakan oleh pemilik untuk penentuan stok bahan makanan dan minuman serta penentuan paket makanan. Selain itu, asosiasi antar souvenir bisa dimanfaatkan untuk menata pengaturan souvenir di minimarket "Wisanggeni Coffee"

2. Latar belakang pemilik dan karyawan yang tidak di bidang komputer, membuat perlu adanya sosialisasi penggunaan aplikasi di akhir kegiatan pengabdian masyarakat yang diusulkan. Tujuan sosialisasi ini agar pemilik ataupun karyawan bisa menggunakan aplikasi dengan benar dan bisa membaca luaran aplikasi yang terkait dengan pola pembelian konsumen dengan tepat. Sosialisasi dilakukan sebanyak 2 kali dengan target pemilik dan karyawan familiar dengan menu-menu yang ada di aplikasi dan bisa memahami output dari aplikasi.

Target luaran dari kegiatan abdimas dapat dilihat pada Tabel 1. Adapun luaran hasil dari kegiatan pengabdian masyarakat ini yang terpenuhi adalah :

1. Proseding kegiatan pengabdian masyarakat

2. Laporan akhir kegiatan

3. Program aplikasi yang akan dipakai oleh mitra

Tabel 1.

TARGET LUARAN

\begin{tabular}{|c|c|c|c|}
\hline No & Permasalahan & Solusi & Hasil Capaian \\
\hline 1 & $\begin{array}{l}\text { Persaingan bisnis yang ketat membuat trend } \\
\text { penjualan semakin hari stagnan bahkan } \\
\text { terkadang menurun }\end{array}$ & $\begin{array}{l}\text { Perlu dilakukan Analisa } \\
\text { pada penjualan menu } \\
\text { makanan dan souvenir tiap } \\
\text { peridode }\end{array}$ & $\begin{array}{l}\text { Dataset penjualan tiap bulan } \\
\text { dianalisa sebagai dataset }\end{array}$ \\
\hline 2 & $\begin{array}{l}\text { Pemilik kesulitan untuk mendapatkan pola } \\
\text { pembelian konsumen }\end{array}$ & $\begin{array}{l}\text { Membuat aplikasi } \\
\text { menggunakan algoritma } \\
\text { apriori untuk mendapatkan } \\
\text { pola pembelian }\end{array}$ & $\begin{array}{l}\text { Aplikasi berhasil dibuat dan } \\
\text { bisa digunakan untuk } \\
\text { menganalisa pola pembelian } \\
\text { konsumen }\end{array}$ \\
\hline 3 & $\begin{array}{l}\text { Pola pembelian yang tidak terprediksi membuat } \\
\text { pemilik "Wisanggeni Coffee" kesulitan dalam } \\
\text { penentuan stok bahan makanan, minuman dan } \\
\text { souvenir yang dijual. Akibatnya stok bahan } \\
\text { makanan dan minuman yang tidak bisa tahan } \\
\text { lama seringkali terbuang karena tidak laku } \\
\text { terjual. }\end{array}$ & $\begin{array}{ll}\text { a. } & \text { Membuat aplikasi } \\
\text { menggunakan } \\
\text { algoritma apriori untuk } \\
\text { mendapatkan pola } \\
\text { pembelian } \\
\text { b. } \\
\text { Pemilik / karyawan } \\
\text { belajar membaca hasil } \\
\text { output dari aplikasi } \\
\text { untuk melakukan } \\
\text { restok barang }\end{array}$ & $\begin{array}{ll}\text { a. } & \text { Aplikasi berhasil dibuat } \\
\text { b. } & \text { Karyawan melalui } \\
\text { pelatihan dan modul } \\
\text { mampu untuk membaca } \\
\text { dan menganalisa output } \\
\text { dari aplikasi untuk } \\
\text { mengenali pola pembelian } \\
\text { konsumen }\end{array}$ \\
\hline 4 & $\begin{array}{l}\text { Kurang terprediksinya pola konsumen juga } \\
\text { membuat "Wisanggeni Coffee" seringkali } \\
\text { kehilangan kesempatan untuk menjual } \\
\text { makanan, minuman dan souvenir karena out of } \\
\text { stock. }\end{array}$ & $\begin{array}{ll}\text { a. } & \text { Menawarkan menu } \\
\text { berdasarkan pola } \\
\text { asosiasi aplikasi } \\
\text { b. } \\
\text { Menyusun tata letak } \\
\text { souvenir berdasarkan } \\
\text { pola asosiasi dari } \\
\text { aplikasi }\end{array}$ & $\begin{array}{l}\text { Karyawan melalui pelatihan } \\
\text { dan modul, mampu: } \\
\text { - } \quad \text { menawarkan menu dalam } \\
\text { periode tertentu } \\
\text { berdasarkan pola } \\
\text { pembelian konsumen } \\
\text { - } \\
\text { menyusun tata letak } \\
\text { souvenir dalam periode } \\
\text { tertentu berdasarkan pola } \\
\text { pembelian konsumen }\end{array}$ \\
\hline
\end{tabular}

Untuk menentukan pola pembelian yang dilakukan bersamaan selama kurun waktu tertentu maka akan digunakan algoritma apriori (Harianto \& Eddy, 2020). Algoritma apriori termasuk jenis aturan asosiasi pada data mining. Aturan yang menyatakan asosiasi antara beberapa atribut sering disebut affinity analysis atau market basket analysis(Kusrini, 2005). 
Selain itu algoritma apriori juga dapat dengan cepat memproses kecenderungan pola suatu itemset yang memiliki beberapa kombinasi(Tana et al., 2018). Analisis asosiasi atau association rule mining adalah teknik data mining untuk menemukan aturan suatu kombinasi item. Salah satu tahap analisis asosiasi yang menarik perhatian banyak peneliti untuk menghasilkan algoritma yang efisien adalah analisis pola frequensi tinggi (frequent pattern mining)(Kholis et al., 2018). Penting tidaknya suatu asosiasi dapat diketahui dengan dua tolak ukur, yaitu: support dan confidence. Support (nilai penunjang) adalah persentase kombinasi item tersebut dalam database, sedangkan confidence (nilai kepastian) adalah kuatnya hubungan antar-item dalam aturan asosiasi(Bumbary, 2017). Selanjutnya nilai support dan confidance ini akan dicari nilai minimumnya(Satie et al., 2020). Tahap awal dalam algoritma apriori adalah analisis pola frekuensi tinggi yaitu dengan cara mencari kombinasi item yang memenuhi syarat minimum dari nilai support dalam basis data, Nilai support sebuah item diperoleh dengan rumus berikut(Kusumo et al., 2016)

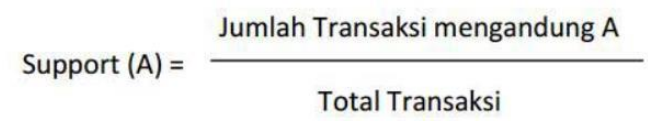

Sementara nilai support dua item menggunakan rumus sebagai berikut:

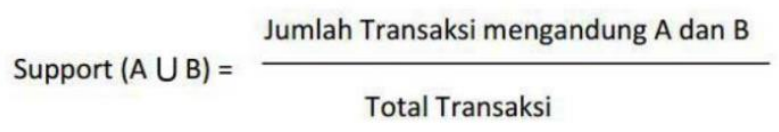

Frequent itemset menunjukkan itemset yang memiliki frekuensi kemunculan lebih dari nilai minimum yang ditentukan.

Tahap selanjutnya adalah pembentukan aturan asosiasi, yaitu setelah semua pola frekuensi tinggi ditemukan, barulah dicari aturan asosiasi yang memenuhi syarat minimum confidence dengan menghitung confidence $\mathrm{A}-\mathrm{B}$. Nilai confidence dari aturan A- B diperoleh rumus berikut(Santoso, 2017)(Triayudi \& Hervian, 2017). Ketika syarat minimum untuk pencarian nilai confidance sudah tidak terpenuhi, maka pencarian nilai untuk confidance akan dihentikan(Napitupul et al., 2019)

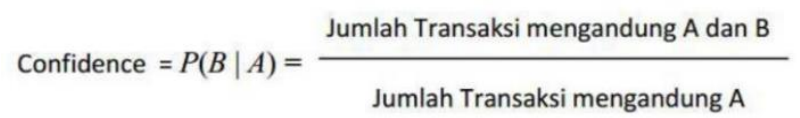

Untuk menentukan aturan asosiasi yang akan dipilih maka harus diurutkan berdasarkan support $\mathrm{x}$ confidence. Aturan diambil sebanyak $\mathrm{n}$ aturan yang memiliki hasil terbesar.

\section{METODE PELAKSANAAN}

Metode pelaksanaan dari kegiatan pengabdian masyarakat ini dibutuhkan kerjasama dari mitra dan pengusul. Seperti yang terlihat di gambar 2, mitra menyediakan daftar makanan, minuman dan souvenir yang dijual di "Wisanggeni Coffee". Mitra juga harus menyediakan daftar transaksi pembelian yang dilakukan oleh konsumen minimal 1 bulan sebelumnya. Daftar ini selanjutnya akan digunakan sebagai dataset pada aplikasi yang akan dibangun oleh pengusul. Aplikasi dibangun dengan metode Apriori. Namun sebelum aplikasi dibangun, pengusul akan melakukan survei terlebih dahulu ke mitra. Survei ini dilakukan untuk mendapatkan data seperti:

1. Lokasi : pengusul melakukan survei lokasi untuk melihat apakah perangkat yang akan digunakan dalam pembangunan aplikasi bisa diimplementasikan. Rencana awal, program akan dibuat berbasis web, sehingga pengusul perlu untuk mengujicobakan beberapa operator internet. Dari proses survey dan ujicoba, ternyata operator yang memiliki sinyal terbaik adalah Telkomsel. 
2. Spesifikasi laptop yang ada di "Wisanggeni Coffee". Data ini pengusul dapatkan dengan berkomunikasi via whataapp.

Hasilnya, ternyata di "Wisanggeni Coffee" sudah memiliki laptop dengan spesifikasi

a. Processor: Intel core i3 $7020 \mathrm{U}(2,3 \mathrm{GHz})$

b. Jumlah core (inti) : 2

c. Benchmark Single Score : 1279

d. Benchmark Total Score : 3493

e. Ram : 4 GB

f. VGA : Intel® HD Graphics 620

g. Benchmark VGA G3D Mark : 929

h. Layar : 14 inch, HD

i. Harddisk : Analog, Kapasitas 1 TB, 5400 RPM

j. Sistem Operasi : Windows 10

3. Survei sumberdaya manusia. Survei ini dilakukan untuk mendapatkan data mengenai konten sosialisasi yang akan dilakukan.

Pemilik dan karyawan "Wisanggeni Coffee" familiar dengan komputer dan beberapa program aplikasi dasar, sehingga ketika aplikasi diimplementasikan tidak akan ada kendala yang cukup berarti. Setelah survei dilakukan, langkah selanjutnya adalah pembangunan aplikasi dan sosialisasi kepada pemilik maupun karyawan "Wisanggeni Coffee".

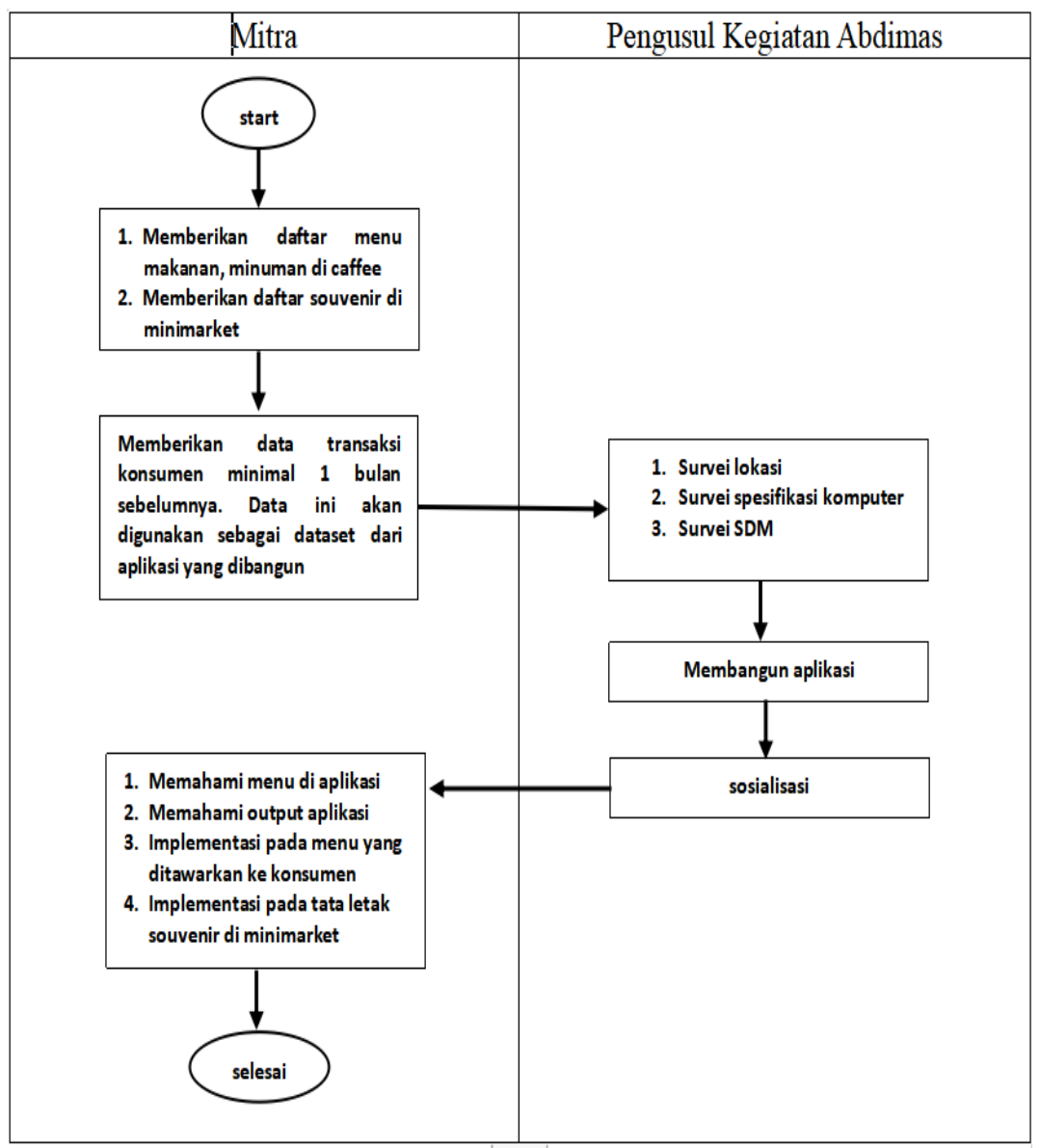

Gambar 2. Spot Wisanggeni Coffee 


\section{HASIL DAN PEMBAHASAN}

Berikut adalah tampilan dari aplikasi asosiasi pola penjualan di "Wisanggeni Coffee" :

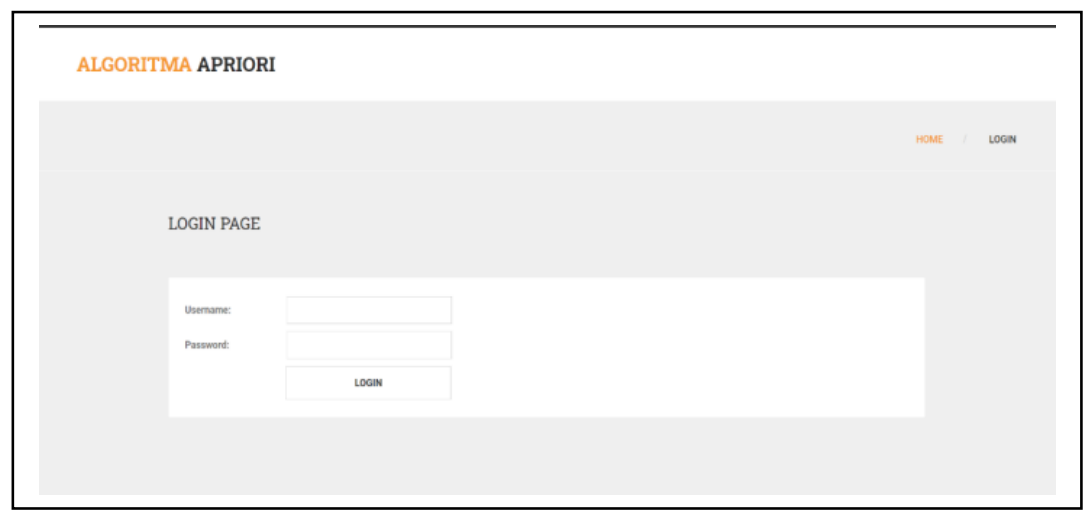

Gambar 3. Halaman login

halaman login digunakan untuk masuk kedalam sistem dengan memasukkan username dan password yang telah dimasukkan oleh pemilik sebelumnya

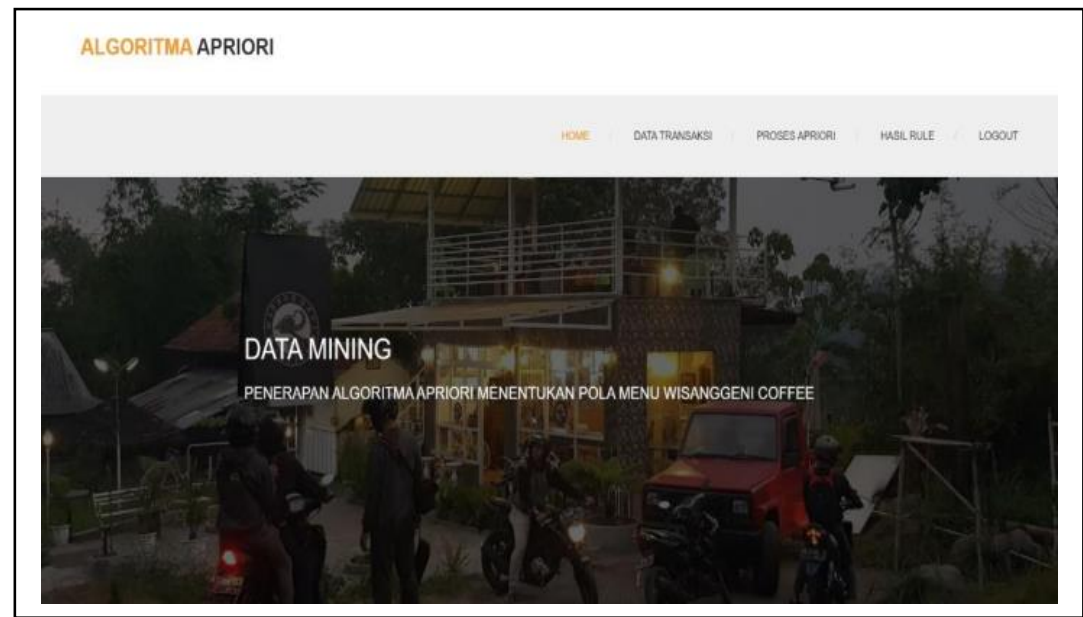

Gambar 4. Halaman utama

halaman home yang digunakan ketika user sudah berhasil login, dalam tampilan ini ada beberapa sub menu untuk masuk atau menjalankan sistem

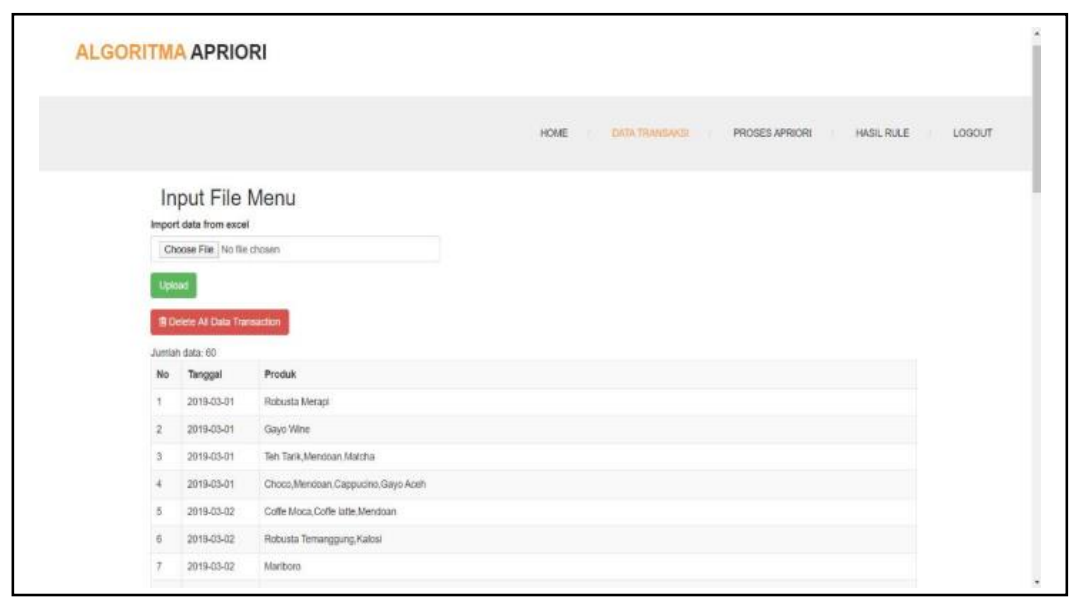

Gambar 5. Halaman transaksi 
halaman data transaksi digunakan untuk upload data transaksi / menu untuk dijadikan bahan perhitungan algoritma apriori, halaman ini juga bisa menghapus data yang telah diinputkan.

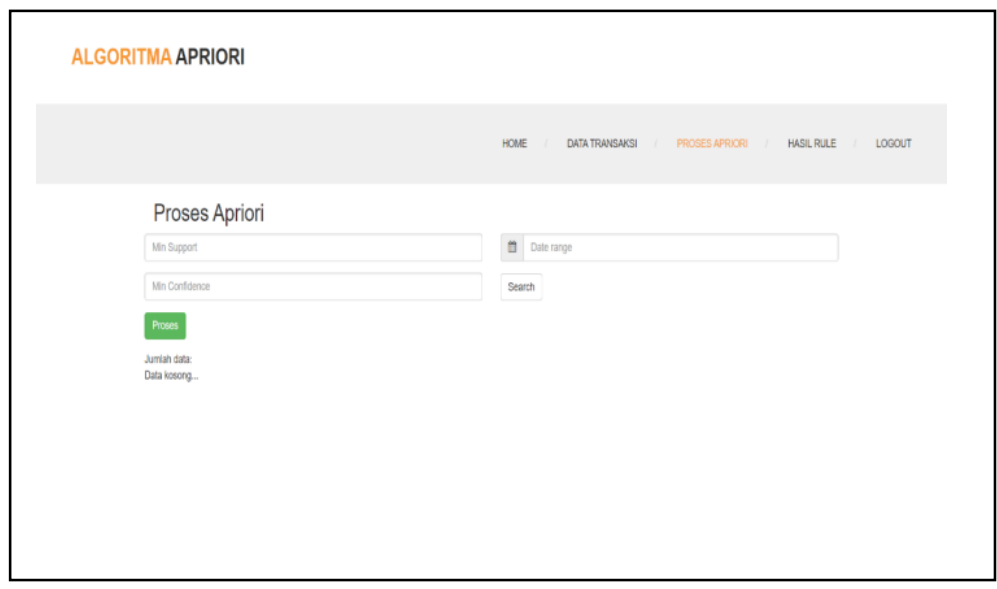

Gambar 6. Halaman proses apriori

halaman proses apriori digunakan untuk menentukan nilai dari min support dan nilai min confidence serta menentukan rentang tanggal data transaksi yang akan dihitung.

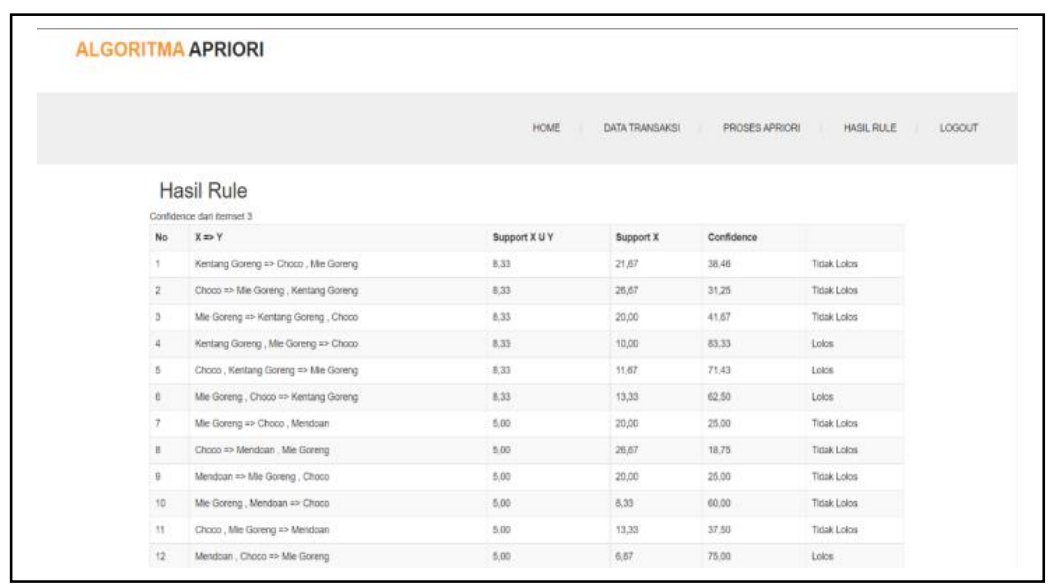

Gambar 7. Halaman asosiasi antar menu

Halaman ini berisi asosiasi atau keterkaitan antara menu satu dengan menu lainnya hasil pembelajaran algoritma asosiasi pada dataset penjualan. Hasil asosiasi ini bisa digunakan untuk memberikan rekomendasi makanan pada customer.

Selain itu, hasil asosiasi ini juga bisa digunakan sebagai rekomendasi tata letak souvenir yang dipajang di rak penjualan.

Kegiatan sosialisasi dilaksanakan pada :

Hari : Sabtu

Tanggal : 7 Maret 2020

Jam : $15.00 \mathrm{WIB}$

Tempat : Wisanggeni Cofee

Kegiatan tersebut sudah terlaksana dengan baik sesuai dengan permintaan dan permasalahan yang dihadapi oleh mitra terpilih, yang dapat dibuktikan dengan gambaran sebagai berikut : 


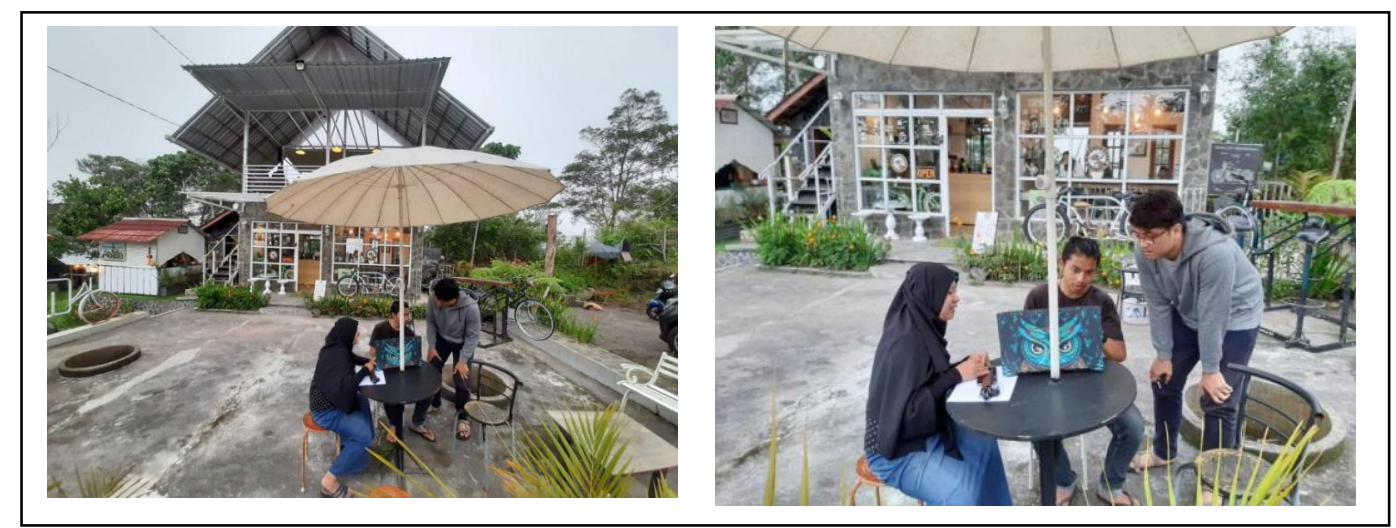

Gambar 8. Sosialisasi penggunaan aplikasi pada karyawan Wisanggeni Coffee

\section{KESIMPULAN}

Dari kegiatan yang dilakukan didapatkan beberapa catatan yaitu bahwa keinginan pemilik dalam membangun sistem asosiasi cukup baik. Pemilik langsung menerapkan aplikasi baik dalam pola menawarkan menu maupun mengatur tata letak souvenir di rak penjualan. Sedangkan dari sisi potensi ekonomi, sebelumnya kami menargetkan sampai pada evaluasi hasil penerapan aplikasi apakah bisa meningkatkan penjualan "Wisanggeni Coffee". Namun karena pandemi Covid-19 tidak kunjung selesai, evaluasi ini kami tunda hingga kegiatan wisata pulih kembali.

\section{UCAPAN TERIMAKASIH}

Penulis mengucapkan terima kasih kepada "Wisanggeni Caffee" dan Universitas Amikom Yogyakarta yang telah memberi dukungan financial terhadap penelitian ini.

\section{DAFTAR PUSTAKA}

Bumbary, T. M. (2017). Utilizing a network of wireless weather stations to forecast weather in developing countries. ISEC 2017 - Proceedings of the 7th IEEE Integrated STEM Education Conference, OO(c), 109-111. https://doi.org/10.1109/ISECon.2017.7910223

Harianto, H., \& Eddy, H. (2020). Analisa data transaksi penjualan barang menggunakan algoritme Apriori dan FP-Growth. Jnanaloka, l(1), 35-43. https://doi.org/10.36802/jnanaloka.2020.v1-no1-6

Kholis, N. K., Sumarmawati, E. D., \& Mutmainah, H. M. (2018). FAKTOR-FAKTOR YANG MEMPENGARUHI NILAI PERUSAHAAN. Jurnal Analisis Bisnis Ekonomi. https://doi.org/10.31603/bisnisekonomi.v16i1.2127

Kusrini, E. T. L. (2005). Data Mining Data mining. In Mining of Massive Datasets. https://doi.org/10.1017/CBO9781139058452.002

Kusumo, D. S., Bijaksana, M. A., \& Darmantoro, D. (2016). DATA MINING DENGAN ALGORITMA APRIORI PADA RDBMS ORACLE. TEKTRIKA - Jurnal Penelitian Dan Pengembangan Telekomunikasi, Kendali, Komputer, Elektrik, Dan Elektronika. https://doi.org/10.25124/tektrika.v8i1.215

Napitupul, G. T., Oktaviani, A., Sarkawi, D., \& Yulianti, I. (2019). Penerapan Data Mining Terhadap Penjualan Pipa Pada Cv. Gaskindo Sentosa Menggunakan Metode Algoritma Apriori. Jurnal Riset Informatika, 1(4), 167-172. https://doi.org/10.34288/jri.v1i4.96

Santoso, H. (2017). Data Mining Penyusunan Buku Perpustakaan Daerah Lombok Barat 
Menggunakan Algoritma Apriori. Seminar Nasional TIK Dan Ilmu Sosial (SocioTech), $25-35$.

Satie, D. E., Suparni, S., \& Pohan, A. B. (2020). Analisa Algoritma Apriori Pada Pola Peminjaman Buku di Perpustakaan ITB Ahmad Dahlan. Jurnal Media Informatika Budidarma, 4(1), 136. https://doi.org/10.30865/mib.v4i1.1475

Tana, M. P., Marisa, F., \& Wijaya, I. D. (2018). Penerapan Metode Data Mining Market Basket Analysis Terhadap Data Penjualan Produk Pada Toko Oase Menggunakan Algoritma Apriori. $J$ I $I$ M $P$ - Jurnal Informatika Merdeka Pasuruan, 3(2), 17-22. https://doi.org/10.37438/jimp.v3i2.167

Triayudi, A., \& Hervian, H. (2017). Mengukur Tingkat Pembiayaan Kredit Pada PT . Trihamas Finance Menggunakan Algoritma Apriori-Data Mining. Jurnal ProTekInfo, 4, 1-5. https://doi.org/https://doi.org/10.30656/protekinfo.v4i0.405 